\title{
PERANCANGAN APLIKASI AKUNTANSI PABRIK BERBASIS WEBSITE
}

\author{
${ }^{1}$ Fritz Gamaliel ${ }^{*},{ }^{2}$ P. Yudi Dwi Arliyanto \\ ${ }^{1,2}$ Politeknik Meta Industri Cikarang \\ Jalan. Inti 1 Blok C1 No 7, Lippo Cikarang \\ *e-mail:fritzgamaliel@politeknikmeta.ac.id
}

Received: 17-07-2021, Revised: 18-07-2021, Accepted: 18-07-2021

\begin{abstract}
Abstrak
Informasi keuangan yang telah dibuat oleh akuntan saat ini dapat dengan mudah diakses oleh bagian pimpinan. Namun ada kendala yang ditemukan oleh pimpinan maupun para akuntan, salah satunya yaitu ketidakseragaman format dokumen keuangan. Hal tersebut mengakibatkan divisi terkait harus menginput data dokumen keuangan yang menjadi tugas divisinya ke dalam sistem. Setelah itu, divisi tersebut mengirimkan dokumennya ke akuntan untuk kemudian akuntan menginputkannya kembali ke dalam sistem. Hal tersebut menyebabkan pekerjaan menjadi tidak efisien karena harus dua kali entri. Dalam penelitian ini, aplikasi dibuat dengan konsep menyeragamkan format dokumen keuangan sehingga cukup sekali entri. Aplikasi dibuat dengan menggunakan bahasa pemograman PHP dan database MySQL. Dengan hadirnya kegiatan penelitian kali ini diharapkan agar Aplikasi dapat meningkatkan mutu laporan keuangan dalam proses pencatatan laporan keuangan.
\end{abstract}

Kata kunci: Akuntansi, Laporan Keuangan, Website, PHP, MySQL.

\begin{abstract}
The financial information that has been made by the accountant can now be easily accessed by the part of the leadership. However there are difficulties faced by the leaders as well as accountants, one that is non-uniformity of financial document format. This has resulted in the related division must input the financial document data which is the task of their division into the system. After that, the division sends the documents to the accountant for then the accountant enters it back into the system. This causes work to be inefficient because it has to be entered twice. In this research, the application was made with the concept of uniform financial document formats so that one entry is sufficient. Application is made using the PHP programming language and MySQL database. The existence of the study expected that Application can improve the quality of financial reporting in the process recording the financial report
\end{abstract}

Keywords: Accounting, Financial Report, Website, PHP, MYSQL

\section{Pendahuluan}

Seiring perkembangan teknologi yang semakin cepat dan perubahan terjadi begitu signifikan, kebutuhan akan hal yang berkaitan erat dengan lingkungan kehidupan semakin banyak, dalam penelitian ini pengolahan data transaksi secara manual tidak menjadi masalah, tetapi yang menjadi masalah apabila banyaknya transaksi yang ada diolah menggunakan sistem pencatatan manual. Hal tersebut akan menghambat pekerjaan, karena banyaknya transaksi yang harus di input, serta tahapantahapan yang harus dibuat, jika menggunakan pencatatan secara manual. Yang ditugaskan dalam melakukan penyusunan laporan keuangan adalah seorang akuntan sebagai sarana untuk memonitor kemajuan suatu perusahaan atau dapat juga digunakan sebagai sarana pengambilan keputusan. 


\section{DOI: https://doi.org/10.52362/jmijayakarta.v1i3.497}

Suatu perubahan diperlukan dalam berbagai aspek misalkan bentuk penyajian informasi, sehingga informasi dapat efektif dan mudah dipahami. Sumber informasi dari sebuah laporan keuangan banyak dijadikan pedoman dalam pengambilan sebuah keputusan bagi para kreditur, pengamat ekonomi, pemegang saham, dan pemerintah sesuai dengan kepentingan yang ada, serta merupakan pedoman perincian pada setiap prestasi operasional suatu perusahaan ketika Analisa Rasio Keuangan dilakukan. Dengan adanya laporan keuangan maka akan diperoleh gambaran mengenai bagaimana perkembangan perusahaan, sehingga yang berkepentingan terhadap perkembangan perusahaan dapat mengadakan analisis terhadap semua data keuangan yang terdapat dalam laporan keuangan.

Dalam praktek lapangan, masih ditemukan adanya ketidakseragaman format dokumen keuangan. Hal tersebut mengakibatkan divisi terkait harus menginput data dokumen keuangan yang menjadi tugas divisinya ke dalam sistem. Setelah itu, divisi tersebut mengirimkan dokumennya ke akuntan untuk kemudian akuntan menginputkannya kembali ke dalam sistem. Hal tersebut menyebabkan pekerjaan menjadi tidak efisien karena harus dua kali entri. Dalam penelitian ini, aplikasi dibuat dengan konsep menyeragamkan format dokumen keuangan sehingga cukup sekali entri.

\section{Tinjauan Literatur}

Penelitian terdahulu dilakukan oleh Untung Rahardja dkk yang berjudul "Penerapan Software Akuntansi Online Sebagai Penunjang Pencatatan Laporan Keuangan" [1]. Berdasarkan penelitian tersebut yaitu adanya Software Jurnal dinilai dapat mengurangi banyaknya penggunaan kertas untuk membuat sebuah laporan keuangan apabila terdeteksi kesalahan karena akuntan hanya tinggal mengedit data yang salah, maka data tersebut akan dihitung kembali secara otomatis untuk dijadikan sebuah laporan keuangan

Penelitian terdahulu dilakukan oleh Bintang Chandra dan Hendro Poerbo yang berjudul "Sistem Informasi Akuntansi Berbasis Web Pada Perusahaan Jasa Tenaga Kerja" [2]. Berdasarkan penelitian tersebut yaitu hasil akhir yang didapat adalah pelaporan Jurnal Umum, Buku Besar, Neraca Saldo, Jurnal Penyesuaian, Neraca Saldo sesudah Penyesuaian, Laporan Laba Rugi, Laporan Perubahan Modal, dan Neraca Akhir.

Penelitian terdahulu dilakukan oleh Iyus Supriadi dan Amir Jono yang berjudul "Sistem Informasi Akuntansi Berbasis Website Pada UD. Surya Ponsel Abepura" [3]. Berdasarkan penelitian tersebut yaitu sistem memberikan kemudahan bagi Pemilik Toko untuk melihat keadaan keuangan di Ud. Surya Ponsel sebagai informasi untuk mengambil keputusan.

Penelitian terdahulu dilakukan oleh Megawati dan Ichsyan Rizky Adi Putra yang berjudul "Rancang Bangun Sistem Informasi Akuntansi Berbasis Web" [4]. Berdasarkan penelitian tersebut yaitu sistem informasi akuntansi berbasis web pada PT. Kalber Reksa Abadi mampu mengolah data keuangan dan akuntansi secara terkomputerisasi

Penelitian terdahulu dilakukan oleh Johandri Iqbal dan Yuventina Laura Hoba yang berjudul "Perancangan Sistem Informasi Akuntansi Penjualan Berbasis Web Pada Saiioproject Jambi" [5]. Berdasarkan penelitian tersebut yaitu sistem ini dirancang hanya untuk pemakaian internal agar dapat mempermudah dalam pencatatan dan pembuatan laporan penjualan nantinya

Penelitian terdahulu dilakukan oleh Putu Roy Nurbhawa dkk yang berjudul "Sistem Informasi Akuntansi Perhotelan Berbasis Web" [6]. Berdasarkan penelitian tersebut yaitu fitur yang terdapat pada sistem informasi akuntansi pada Bakung Ubud mampu mengelola transaksi dan menghasilkan laporan keuangan yang relevan bagi perusahaan

Penelitian terdahulu dilakukan oleh Sufajar Butsianto dan Eka Febriliani yang berjudul "Rancang Bangun Sistem Informasi Akuntansi Berbasis Web (Studi Kasus : PT. Yuju Indonesia)" [7]. Berdasarkan penelitian tersebut yaitu sistem yang dibangun menghasilkan output laporan penjualan dan pembelian, jurnal umum, buku besar, laporan laba rugi serta neraca saldo yang dapat ditampillkan berdasarkan periode tertentu.

Penelitian terdahulu dilakukan oleh Muhammad Nurrizky Ekaputra dkk yang berjudul "Rancang Bangun Sistem Informasi Akuntansi PT. Zenith Material Solution Berbasis Web" [8]. Berdasarkan 
DOI: https://doi.org/10.52362/jmijayakarta.v1i3.497

penelitian tersebut yaitu mengintegrasikan antara data transaksi dengan penjurnalan yang dibuktikan dengan input data transaksi yang secara otomatis menambahkan ayat jurnal pada halaman jurnal umum dan jurnal transaksi.

Penelitian terdahulu dilakukan oleh Moch Zawaruddin Abdullah dkk yang berjudul "Rancang Bangun Sistem Informasi Akuntansi Berbasis Website menggunakan Framework Laravel" [9]. Berdasarkan penelitian tersebut yaitu sistem yang telah dikembangkan sangat membantu pegiat UKM Batik Ron Tuwuh dan UKM Bordir Prohandji dalam melakukan pengelolaan transaksi keuangan.

Penelitian terdahulu dilakukan oleh Stefen Ongko Saputro dkk yang berjudul "Perancangan dan Pembuatan Sistem Informasi Akuntansi Berbasis Web pada Toko Konveksi Gracia Sprei Tulungagung" [10]. Berdasarkan penelitian tersebut yaitu aplikasi mampu memberikan laporan keuangan walaupun masih ada laporan yang kurang dengan penilaian kelengkapan informasi yang dibutuhkan $66.66 \%$ cukup dan $33.33 \%$ kurang.

Penelitian terdahulu dilakukan oleh Nanda Rizqya yang berjudul "Perancangan Sistem Informasi Akuntansi Laporan Posisi Keuangan Pada UMKM Berbasis Web (Studi Kasus UMKM Home Catering)" [11]. Berdasarkan penelitian tersebut yaitu peneliti menghasilkan rancangan berupa ERD(Entity Relationship Diagram), Nomor akun dan nama akun usulan,dan User Interface.

Penelitian terdahulu dilakukan oleh Ni Putu Dita Ariani Sukma Dewi dkk yang berjudul "Rancang Bangun Sistem Informasi Akuntansi Pada CV. Manik Galih Berbasis Website" [12]. Berdasarkan penelitian tersebut yaitu didapatkan hasil bahwa fitur-fitur pada sistem yang dibangun sesuai dengan rancangan dan telah berjalan dengan baik..

Penelitian terdahulu dilakukan oleh Lucky Hardiyanti Kartika Haris dkk yang berjudul "Rancang Bangun Sistem Informasi Akuntansi di STIKI Copy Center" [13]. Berdasarkan penelitian tersebut yaitu didapatkan hasil bahwa fitur -fitur yang terdapat pada Sistem Informasi Akuntansi di STIKI Copy Center dapat berjalan dengan baik sesuai dengan yang diharapkan.

Penelitian terdahulu dilakukan oleh Fendy Haryanto Hansen dkk yang berjudul "Perancangan dan Pembuatan Aplikasi Sistem Informasi Akuntansi Berbasis Web pada Toko Bahan Bangunan UD. Surya Mas" [14]. Berdasarkan penelitian tersebut yaitu didapatkan aplikasi juga sudah dapat memberikan laporan keuangan sesuai dengan data yang asli berdasarkan hasil dari pengujian kuesioner sebesar $100 \%$ dengan nilai sangat baik.

Mengacu penelitian-penelitian diatas maka dalam penelitian ini akan dilakukan penelitian suatu aplikasi akuntansi pabrik berbasis web. Sedangkan sistem yang akan dibangun dengan konsep menyeragamkan format dokumen keuangan sehingga cukup sekali entri adalah entri account, edit account, entri document, edit document, reporting dan closing. Hasil closing menjadi data awal periode akuntansi berikutnya.

\section{Metode Penelitian (or Research Method)}

\subsection{Pemodelan Aplikasi Akuntansi Pabrik}

Berikut merupakan pemodelan aplikasi akuntansi pabrik berbasis web 


\subsection{Use case Aplikasi Akuntansi Pabrik}

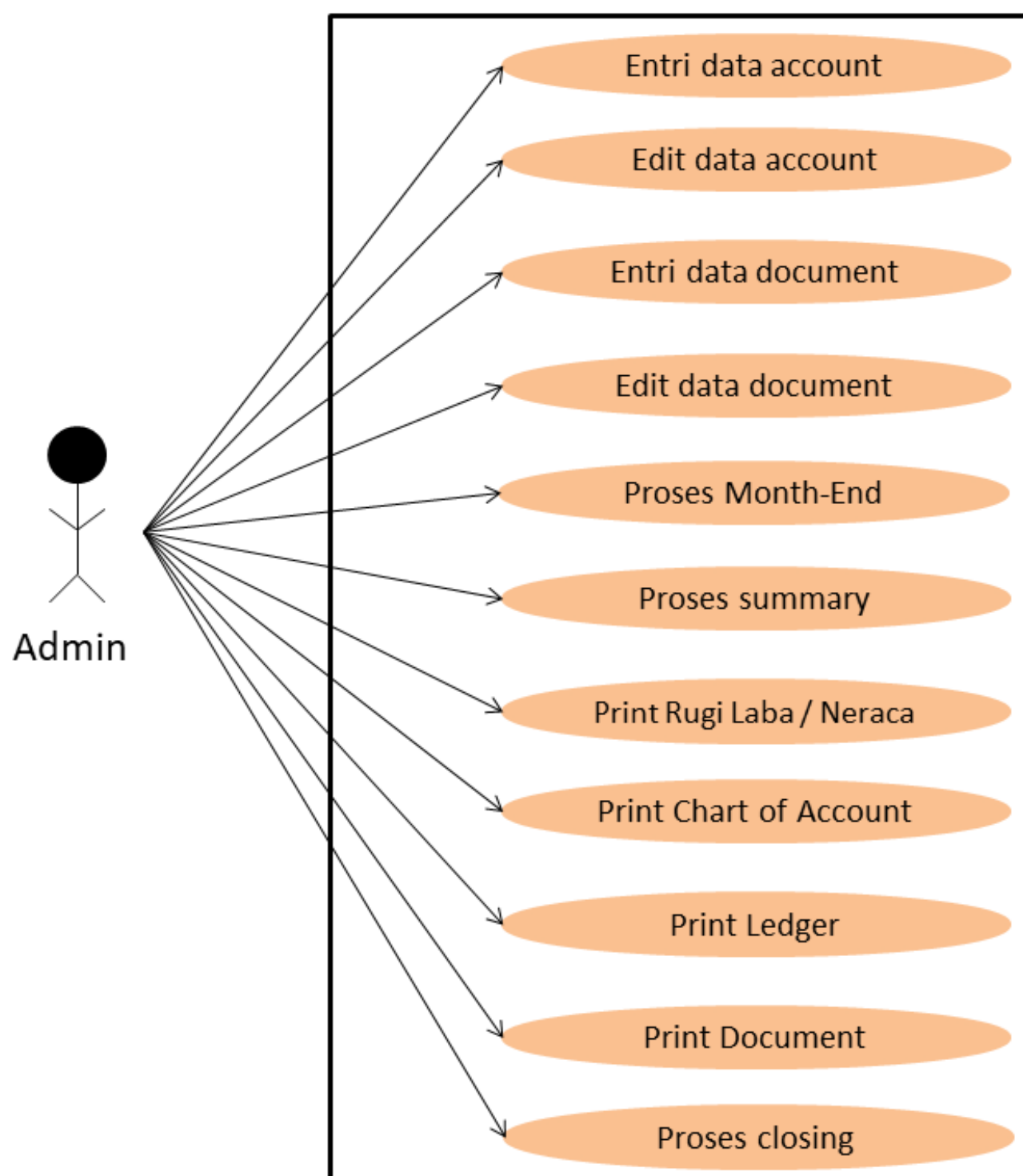

Gambar 1 Rancangan use case diagram

Admin melakukan pengelolahan terhadap aplikasi akuntansi pabrik berbasis web yang meliputi account, document, dan report. Account yang dikelola yaitu Aset, Liabilitas \& Ekuitas, Pendapatan, Beban Produksi, Konsumsi Bahan Baku, Beban Penjualan, Beban Umum \& Administrasi, Pendapatan Lain-lain, Beban Lain-lain, Pajak Perusahaan. Document yang dikelola yaitu Customer Invoice (Penjualan), Supplier Bill (Pembelian), Material Consumption (Gudang Bahan Baku), Goods Receive (Gudang Bahan Baku), Production Report (Produksi), Receive Voucher (Keuangan), Payment Voucher (Keuangan), General Journal (Accounting), Adjustment (Accounting), Opening Balance (Accounting). Report yang dihasilkan yaitu Rugi Laba, Neraca, Chart Of Account, Ledger, dan Document. 


\section{Hasil dan Pembahasan}

DOI: https://doi.org/10.52362/jmijayakarta.v1i3.497

\subsection{Tampilan entri data account}

Digunakan untuk admin entri data account ke dalam aplikasi akuntansi pabrik berbasis web. Tampilan entri data account dapat dilihat pada gambar berikut.
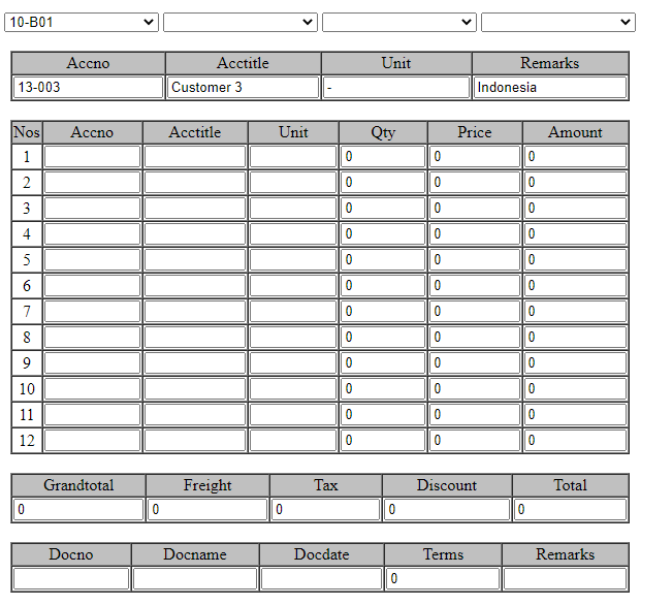

\section{Gambar 2 Tampilan entri data account}

\subsection{Tampilan edit data account}

Digunakan untuk admin edit data account yang ada di dalam aplikasi akuntansi pabrik berbasis web. Tampilan halaman edit data account dapat dilihat pada gambar berikut

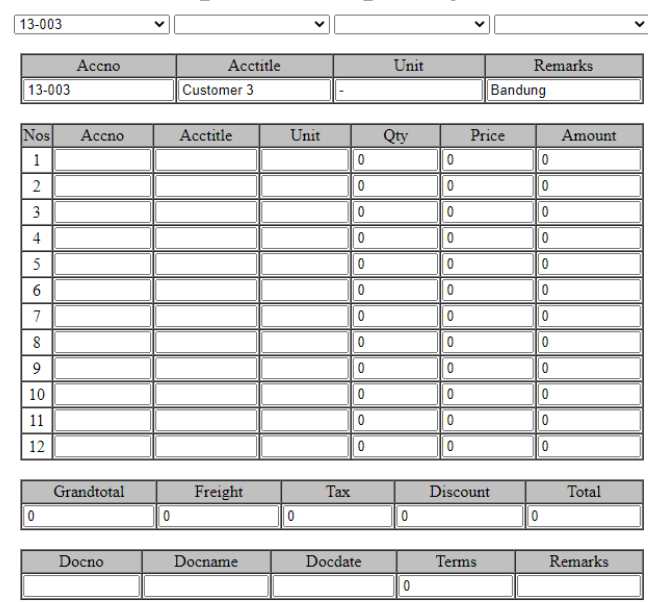

\section{Gambar 3 Tampilan edit data account}

\subsection{Tampilan entri data document}

Digunakan untuk admin entri data dokumen ke dalam aplikasi akuntansi pabrik berbasis web. Tampilan halaman entri data dokumen dapat dilihat pada gambar berikut. 
DOI: https://doi.org/10.52362/jmijayakarta.v1i3.497
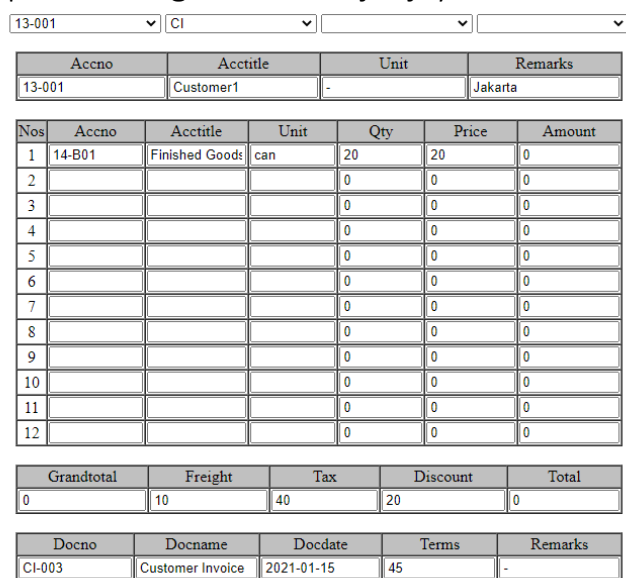

\section{Gambar 4 Tampilan entri data document}

\subsection{Tampilan edit data document}

Digunakan untuk admin edit data dokumen yang ada di dalam aplikasi akuntansi pabrik berbasis web. Tampilan halaman edit data dokumen dapat dilihat pada gambar berikut.

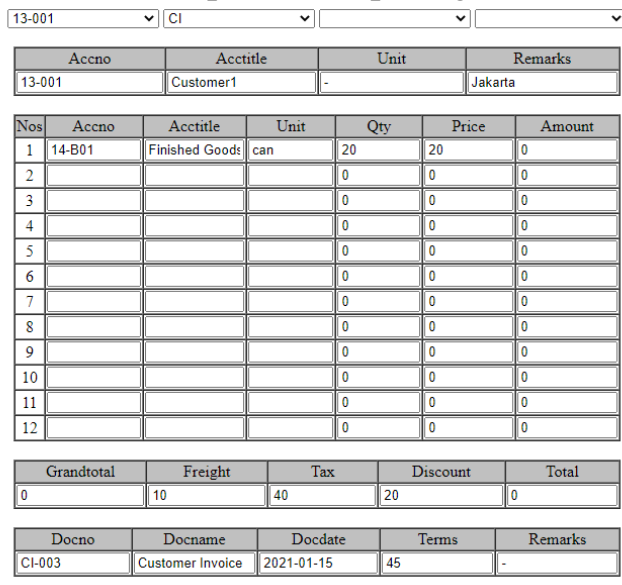

\section{Gambar 5 Tampilan edit data document}

\subsection{Tampilan proses Month-End}

Digunakan untuk admin melaksanakan proses month-end terhadap data yang ada di dalam aplikasi akuntansi pabrik berbasis web. Tampilan halaman proses month-end dapat dilihat pada gambar berikut. 
DOI: https://doi.org/10.52362/jmijayakarta.v1i3.497
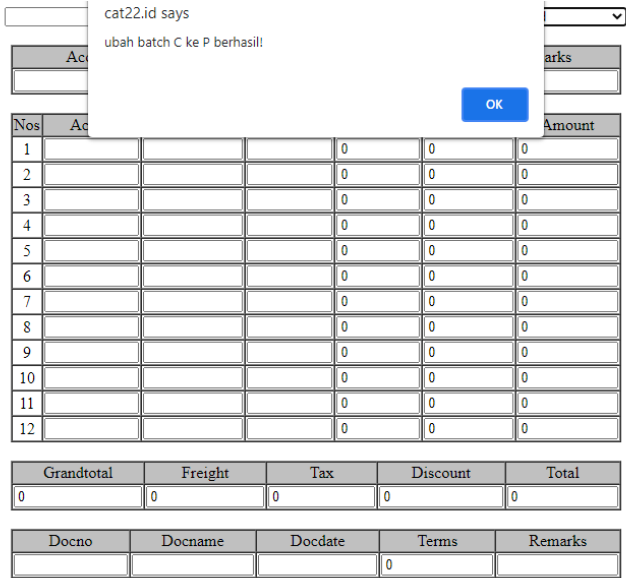

\section{Gambar 6 Tampilan proses Month-End}

\subsection{Tampilan proses Summary}

Digunakan untuk admin melaksanakan proses summary terhadap data yang ada di dalam aplikasi akuntansi pabrik berbasis web. Proses summary adalah proses menghitung saldo akhir setiap account yang ada di dalam aplikasi. Tampilan halaman proses summary dapat dilihat pada gambar berikut.
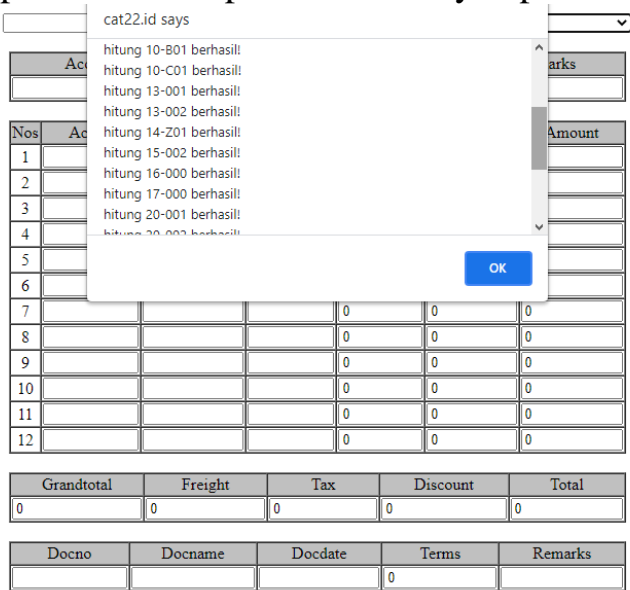

Gambar 7 Tampilan proses Summary

\subsection{Tampilan print Rugi Laba / Neraca}

Digunakan untuk admin mengolah data yang ada di dalam aplikasi menjadi rugi laba dan neraca. Tampilan halaman print rugi laba/neraca dapat dilihat pada gambar berikut. 


$\begin{array}{ll}\text { Daftar Rugi Laba } & \\ \text { 30-A01 Sales } & -1150 \\ \text { 30-B01 Sales Discount } & 70 \\ \text { 30-C01 Freight Income } & -30 \\ \text { 40-A1 Raw Material Consumption } & 846 \\ \text { 40-B01 Finished Goods Difference } & 132.071 \\ \text { 40-C00 Production Overhead } & 50 \\ \text { 50-000 Sales Expenses } & 4 \\ \text { 60-000 General Dept Expenses } & 21 \\ \text { 70-000 Other Income } & -1 \\ \text { 80-000 Other Expenses } & 3 \\ \text { 90-000 Corporate Tax } & 10 \\ \text { 29-Z01 Retained Earning } & -44.929 \\ & \\ \text { Neraca } & \\ \text { 10-B01 Bank } & 110 \\ \text { 10-C01 Cash } & 23 \\ \text { 13-001 Customer1 } & 430 \\ \text { 13-002 Customer2 } & 800 \\ \text { 14-A01 Raw Material A } & 69 \\ \text { 14-A02 Raw Material B } & 75 \\ \text { 14-B01 Finished Goods A } & 215.573 \\ \text { 14-B02 Finished Goods B } & 352.356 \\ \text { 14-Z01 Goods In Transit } & 0 \\ \text { 15-002 Prepaid Tax } & 60 \\ \text { 16-000 Fixed Assets } & 1200 \\ \text { 17-000 Fixed Assets Depreciation } & -35 \\ \text { 10-D01 Tes1 } & 0 \\ \text { Total Assets } & 3299.929 \\ \text { 20-001 Supplier1 } & -400 \\ \text { 20-002 Supplier2 } & -475 \\ \text { 26-001 Tax Payable } & -130 \\ \text { 29-A00 Shareholder } & -2250 \\ \text { 29-Z01 Retained Earning } & -44.9289 \\ \text { Total Liabilities } & -3299.9289 \\ & \\ & \end{array}$

\section{Gambar 8 Tampilan print Rugi Laba / Neraca}

\subsection{Tampilan print Chart of Account}

Digunakan untuk admin melihat chart of account yang ada di dalam aplikasi akuntansi pabrik berbasis web. Tampilan halaman print chart of account dapat dilihat pada gambar berikut.

\begin{tabular}{|c|c|c|c|}
\hline Accno & Acctitle & Unit & Remarks \\
\hline 10-B01 & Bank & - & $\mathrm{A} / \mathrm{C} 1111$ \\
\hline $10-\mathrm{C} 01$ & Cash & - & - \\
\hline $13-001$ & Customer 1 & - & Jakarta \\
\hline $13-002$ & Customer2 & - & Singapore \\
\hline 14-A01 & Raw Material A & $\mathrm{kg}$ & - \\
\hline 14-A02 & Raw Material B & ltr & - \\
\hline 14-B01 & Finished Goods A & can & - \\
\hline 14-B02 & Finished Goods B & can & - \\
\hline $14-Z 01$ & Goods In Transit & - & - \\
\hline $15-002$ & Prepaid Tax & - & - \\
\hline $16-000$ & Fixed Assets & - & - \\
\hline $17-000$ & Fixed Assets Depreciation & - & - \\
\hline $20-001$ & Supplier1 & - & Sydney \\
\hline $20-002$ & Supplier2 & - & Singapore \\
\hline $26-001$ & Tax Payable & - & - \\
\hline $29-\mathrm{A} 00$ & Shareholder & - & - \\
\hline $29-Z 01$ & Retained Earning & - & - \\
\hline
\end{tabular}

\section{Gambar 9 Tampilan print Chart of Account}

\subsection{Tampilan print Ledger}

Digunakan untuk admin melihat ledger yang ada di dalam aplikasi akuntansi pabrik berbasis web. Tampilan halaman print ledger dapat dilihat pada gambar berikut. 
DOI: https://doi.org/10.52362/jmijayakarta.v1i3.497

\begin{tabular}{|c|c|c|c|c|c|c|c|c|c|}
\hline Docno & Docname & Accno & Acctitle & Unit & Terms & Remarks & Qty & Price & Amoun \\
\hline CI- 000 & & & & & 0 & & 0 & 0 & 0 \\
\hline SB-000 & & & & & 0 & & 0 & 0 & 0 \\
\hline MC- 000 & & & & & 0 & & 0 & 0 & 10 \\
\hline GR-000 & & & & & 0 & & 0 & 0 & 0 \\
\hline PR-000 & & & & & 0 & & 0 & 0 & 0 \\
\hline RV-000 & & & & & 0 & & 0 & 0 & 0 \\
\hline PV-000 & & & & & 0 & & 0 & 0 & 0 \\
\hline GJ-000 & & & & & 0 & & 0 & 0 & 0 \\
\hline AD-000 & & & & & 0 & & 0 & 0 & 0 \\
\hline OB- 000 & & & & & 0 & & 0 & 0 & 0 \\
\hline CI-001 & Customer Invoice & 14-B01 & Finished Goods A & can & 45 & t- & -20 & 20 & -400 \\
\hline CI-001 & Customer Invoice & 26-001 & Tax Payable & - & 45 & - & 0 & 0 & -40 \\
\hline CI-001 & Customer Invoice & $30-\mathrm{C} 01$ & Freight Income & 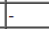 & 45 & - & 0 & 0 & -10 \\
\hline CI-001 & Customer Invoice & 30-B01 & Sales Discount & t & 45 & - & 0 & 0 & 20 \\
\hline CI-001 & Customer Invoice & 13-001 & Customer 1 & - & 45 & - & 0 & 0 & 430 \\
\hline CI-002 & Customer Invoice & $13-002$ & Customer2 & + & 45 & 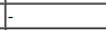 & 0 & 0 & 800 \\
\hline CI-002 & Customer Invoice & 30-B01 & Sales Discount & + & 45 & - & 0 & 0 & 50 \\
\hline CI-002 & Customer Invoice & $30-\mathrm{C} 01$ & Freight Income & - & 45 & - & 0 & 0 & -20 \\
\hline CI-002 & Customer Invoice & $26-001$ & Tax Payable & - & 45 & - & 0 & 0 & -80 \\
\hline CI-002 & Customer Invoice & 14-B02 & Finished Goods B & can & 45 & + & -50 & 15 & -750 \\
\hline SB-001 & Supplier Bill & $20-001$ & Supplier1 & & 0 & See GR-001 & 0 & 0 & -400 \\
\hline SB-001 & Supplier Bill & $15-002$ & Prepaid Tax & - & 0 & See GR-001 & 0 & 0 & 25 \\
\hline SB-001 & Supplier Bill & $14-\mathrm{Z} 01$ & Goods In Transit & - & 0 & See GR-001 & 0 & 0 & 375 \\
\hline SB-002 & Supplier Bill & $20-002$ & Supplier2 & + & 60 & See GR-002 & 0 & 0 & -475 \\
\hline SB-002 & Supplier Bill & $15-002$ & Prepaid Tax & - & 60 & See GR-002 & 0 & 0 & 35 \\
\hline SB-002 & Supplier Bill & $14-Z 01$ & Goods In Transit & F & 60 & See GR-002 & 0 & 0 & 440 \\
\hline
\end{tabular}

Gambar 9 Tampilan print Ledger

\subsection{Tampilan print Document}

Digunakan untuk admin melihat document yang ada di dalam aplikasi akuntansi pabrik berbasis web. Tampilan halaman print document dapat dilihat pada gambar berikut.

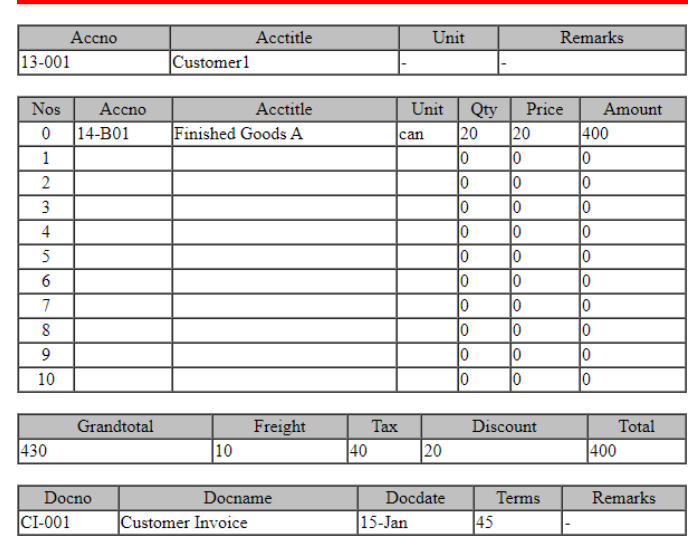

\section{Gambar 10 Tampilan print Document}

\subsection{Tampilan proses Closing}

Digunakan untuk admin melaksanakan proses closing terhadap data yang ada di dalam akuntansi pabrik berbasis web. Hasil closing akan menjadi data awal periode akuntansi berikutnya. Tampilan halaman closing dapat dilihat pada gambar berikut. 
DOI: https://doi.org/10.52362/jmijayakarta.v1i3.497

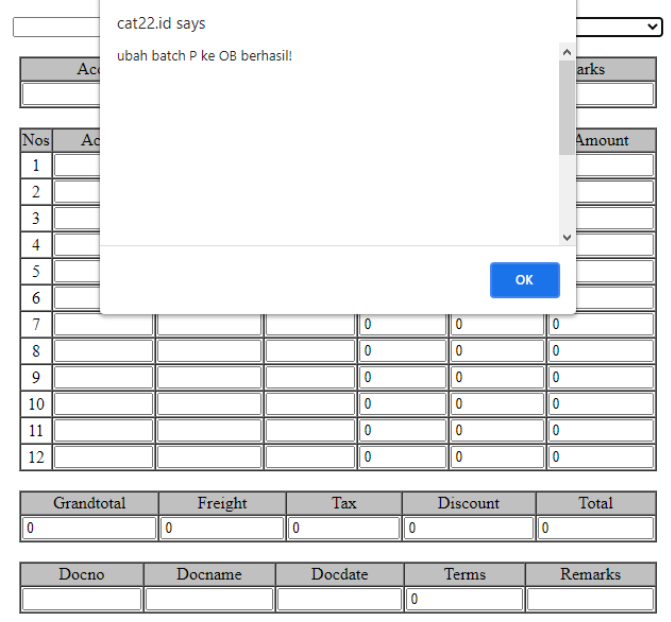

Gambar 11 Tampilan proses Closing

\section{Kesimpulan}

Berdasarkan hasil pembahasan dari bab-bab sebelumnya maka penulis mengambil kesimpulan yaitu :

1. Adanya Aplikasi ini mengefisiensikan pekerjaan karena proses entri cukup sekali saja

2. Aplikasi ini dapat diakses dengan web browser dan berdasarkan pengujian terhadap aplikasi yang dibuat, seluruh fungsi yang ada dalam aplikasi tersebut telah berhasil sesuai dengan fungsinya.

\section{Referensi}

[1] Untung Rahardja dkk. 2018. Penerapan Software Akuntansi Online Sebagai Penunjang Pencatatan Laporan Keuangan. Jurnal Ilmiah SISFOTENIKA

[2] Bintang Chandra dan Hendro Poerbo. 2019. Sistem Informasi Akuntansi Berbasis Web Pada Perusahaan Jasa Tenaga Kerja. Jurnal Teknologi, Informasi, dan Industri

[3] Iyus Supriadi dan Amir Jono. 2018. Sistem Informasi Akuntansi Berbasis Website Pada UD. Surya Ponsel Abepura. Jurnal Teknologi Informasi

[4] Megawati dan Ichsyan Rizky Adi Putra. 2018. Rancang Bangun Sistem Informasi Akuntansi Berbasis Web. Jurnal Sains, Teknologi, dan Industri

[5] Johandri Iqbal dan Yuventina Laura Hoba. 2021. Perancangan Sistem Informasi Akuntansi Penjualan Berbasis Web Pada Saiioproject Jambi. Jurnal of Applied Accounting And Business

[6] Putu Roy Nurbhawa dkk. 2021. Sistem Informasi Akuntansi Perhotelan Berbasis Web. Bangkit Indonesia

[7] Sufajar Butsianto dan Eka Febriliani. 2021. Rancang Bangun Sistem Informasi Akuntansi Berbasis Web (Studi Kasus : PT. Yuju Indonesia). Jurnal Nasional Komputasi dan Teknologi Informasi

[8] Muhammad Nurrizky Ekaputra dkk. 2021. Rancang Bangun Sistem Informasi Akuntansi PT. Zenith Material Solution Berbasis Web. Fountain of Informatics Journal

[9] Moch Zawaruddin Abdullah dkk. 2020. Rancang Bangun Sistem Informasi Akuntansi Berbasis Website menggunakan Framework Laravel. Jurnal Sains, Teknologi dan Industri

[10] Stefen Ongko Saputro dkk. 2020. Perancangan dan Pembuatan Sistem Informasi Akuntansi Berbasis Web pada Toko Konveksi Gracia Sprei Tulungagung. Jurnal Infra 
DOI: https://doi.org/10.52362/jmijayakarta.v1i3.497

[11] Nanda Rizqya. 2020. Perancangan Sistem Informasi Akuntansi Laporan Posisi Keuangan Pada UMKM Berbasis Web (Studi Kasus UMKM Home Catering). Jurnal Ilmiah KOMPUTASI

[12] Ni Putu Dita Ariani Sukma Dewi dkk. 2020. Rancang Bangun Sistem Informasi Akuntansi Pada CV. Manik Galih Berbasis Website. Jurnal Manajemen Informatika \& Komputerisasi Akuntansi

[13] Lucky Hardiyanti Kartika Haris dkk. 2019. Rancang Bangun Sistem Informasi Akuntansi di STIKI Copy Center. Jurnal Sistem Informasi dan Komputer Terapan Indonesia

[14] Fendy Haryanto Hansen dkk. 2019. Perancangan dan Pembuatan Aplikasi Sistem Informasi Akuntansi Berbasis Web pada Toko Bahan Bangunan UD. Surya Mas. Jurnal Infra 